\title{
The correlation of entrepreneurship characteristic, business innovation, and marketing strategy to the resilience of micro, small, and medium enterprises (msme) in the new normal patterns
}

\author{
Aris Slamet Widodo* \\ Departement of Agribusiness, Faculty of Agriculture, University of Muhammadiyah Yogyakarta, \\ Indonesia
}

\begin{abstract}
This study aims to determine the perception of the level of resilience of Micro, Small, and Medium Enterprises (MSME) and determine the factors related to the resilience of MSME in the new normal. This study was conducted on all MSME assisted by the Research, Publication, and Community Service (LP3M) of the University of Muhammadiyah Yogyakarta in community empowermrnt program in August 2020. The respondents were spread througout Indonesia with a total of 135 MSME respondents. The method used is descriptive analysis. The analytical technique using Likerl scale skoring and correlation analysis (Rank Spearman) used to determine the correlation of the factors to MSME resilience in the new normal. The results of the analysis show that the perception of the level of resilience of MSME during the Covid-19 pandemic is in the 'agree' category. The characteristics of entrepreneurship, business innovation, and marketing strategies have a positive and significant relationship with the resilience of MSME in the new normal era.
\end{abstract}

\section{Introduction}

MSME or Micro Small and Medium Enterprises are one of business that Indonesia people have interest in. The products are varied, ranging from handcrafts, food, beverages, fashion, beauty tools, etc. Every year, the number of people in business is increasing and spreading in various corners of the country [1]. MSME is the biggest gathering of financial entertainers in the economy of Indonesia, demonstrated to be a security valve fro the public economy in emergency time, just as being a dynamist of monetary development after the monetary emergency [2].

Indonesian's present monetary essentials are not yet strong, provoking the goverment to keep enabling Micro, Small, and Medium Enterprises (MSME). This area can ingest a huge

\footnotetext{
*Corresponding author: armando1215sw@gmail.com
} 
specialist and give freedoms to MSME to create and rival organizations that utilization capital concentrated [21].

MSME additionally deal with numerous issues. There are restricted working capital, low HR, and absence of information on science and innovation. One more snags looked by MSME is the association with muddled business possibilities and temperamental arranging, vision, and mission. This happen in light of the fact that by and large MSME is pay gathering, implies expanding the pay with the accompanying qualities: is family-possessed business, utilizing moderately basic innovation, need admittance to capital and there is no detachment between business capital and individual necessities [3].

One more issues looked by MSME is the absence of admittance to data, particularly market data. This is a hindrance as far as promoting its producta, because of restricted admittance to showcase data which brings about low market direction and powerless intensity at the worldwide level [22]. The absence of data about the market makes MSME incapable to coordinate their business advancement obviously and concentrate, so that theor improvement is deteriorated [23].

Another issue confronted and turn into the hardest issue currently is making due in another ordinary example, which is a worldwide emergency looked by the entire world. One of the effects of Covid-19 pandemic is MSME in Indonesia, in light of the information from The Ministry of Cooperatives ${ }^{[20]}$. which delineates that 1.785 cooperatives and 163.713 Micro, Small, and Medium Enterprises are influenced by the (Covid-19) pandemic. A large portion of the cooperatives influenced by Covid-19 are occupied with day by day necessities, while the most influenced MSME area is food and drinks [24].

Despite the fact that Covid-19 pandemic has influenced a few issues for MSME and cooperatives, then again, openings have additionally arisen [25,26]. MSME and cooperatives can exploit data and correspondence innovation considering the electronic commmerce in 2020 will arrive at US\$ 130 billion. Electronic exchanging exchanges definitely expanded during Covid-19 pandemic. Items whose deal have expanded are wellbeing items expanded by $90 \%$, items that supporting interests expanded by $70 \%$, food expanded by $350 \%$, and home grown food expanded by $200 \%$ [4]. Facing the new lifestyle and high competiiton makes MSME must be able to face global challenges, such as increasing the development of human resources and technology, product and service innovation, and also expanding marketing area [5].

Entrepreneurial characteristic can affect the development of MSME, entrepreneurial characteristic have a need for success, a desire to take the risk, self-confident, and strong desire to do a business [6]. In addition to entrepreneurial characteristis, there is business innovation. Innovation can be characterized as thought, practice, or item that is viewed as new or another client unit [7]. In addition to entrepreneurial characteristic and business innovation, marketing strategy is a field that can not be separated from the visually independent society. Marketing strategy includes strategy about the elements or variables in marketing mix which is the interaction of four main variables in marketing system, namely product/service, price, distribution, and promotion [6]. Based on this background, this study aims : determine the perception of the level of resilience of Micro, Small, and Medium Enterprises (MSME) and determine the factors related to the resilience of MSME in the new normal.

\section{Research Methods}

Basic method used in this study was descriptive analysis method, which was a research that formulates itself on solving problems in the present, the data were collected, compiled, explained, then analyzed [8]. This study was conducted purposively on MSME in Indonesia that had received the community empowerment program in August 2020 by the Institute for 
Research, Publication, and Community Service (LP3M), University of Muhammadiyah Yogyakarta (UMY). Method that used for determining respondents was carried out by census of 135 respondents (MSME) who were actively involved in community empowerment program activities.

Scoring analysis using Likert scale was used to determine the level of resilence of MSME. Meanwhile, correlation analysis with Rank Spearman was used to analyze factors related to resilience of MSME in new normal era. The resilence of MSME was influenced by entrepreneurial characterisics, business innovation, and marketing strategies. Ho: $r s=0$, meaning that there is no correlation between factors related to MSME resilience. Ha: $r s \neq 0$, meaning that there is a correlation between factors related to MSME resilience.

\section{Result and Discussion}

\subsection{Perception of The Level of MSME's Resilience}

Perception of the level of MSME's resilence is a direct response (acceptance) from something received. According to Slamento and Handayani $(2013)^{[9]}$, perception is process that involves the entry of messages and information in human's brain continuously in contact with the environtment. In this study, perception of the level of MSME's resilence is seen from factors related to resilence of MSME, namely by entrepreneurial characterisics, business innovation, and marketing strategies.

\subsubsection{Entrepreneurial Characteristic}

Entrepreneurial characterisic is defined as attitutes and behaviors possessed by entrepreneurs to achieve success in bussiness. Purwanti, (2013 $)^{[6]}$ explains that entrepreneurial characteristic and individual venture capital collectively have a significant effect on business development.

The score obtained in this study using questionnaire through six indicators which measured using Likert scale such as $1=$ STS (Strongly Disagree), $2=$ TS (Disagree), $3=$ CS (Quite Agree), $4=\mathrm{S}$ (Agree), $5=\mathrm{SS}$ (Strongly Agree).

Table 1. Entrepreneurial Characteristic Variable

\begin{tabular}{|c|c|c|c|c|c|c|c|c|}
\hline \multirow{2}{*}{ Variable } & \multicolumn{5}{|c|}{$\begin{array}{c}\text { Distribution of } \\
\text { Respondent's score }\end{array}$} & \multirow{2}{*}{$\begin{array}{l}\text { Score } \\
\text { Range }\end{array}$} & \multirow{2}{*}{$\begin{array}{l}\text { Score } \\
\text { Avergae }\end{array}$} & \multirow[t]{2}{*}{ Category } \\
\hline & 1 & 2 & 3 & 4 & 5 & & & \\
\hline \multirow{6}{*}{$\begin{array}{l}\text { Entrepreneurial } \\
\text { Characteristic }\end{array}$} & 3 & 11 & 35 & 51 & 35 & $1-5$ & 3.77 & Agree \\
\hline & 1 & 9 & 34 & 59 & 32 & $1-5$ & 3.83 & Agree \\
\hline & 4 & 16 & 35 & 54 & 26 & $1-5$ & 3.61 & Agree \\
\hline & 1 & 6 & 33 & 62 & 33 & $1-5$ & 3.89 & Agree \\
\hline & 3 & 10 & 17 & 47 & 58 & $1-5$ & 4.09 & Agree \\
\hline & 4 & 14 & 18 & 48 & 51 & $1-5$ & 3.95 & Agree \\
\hline \multicolumn{6}{|c|}{ Total } & 6-30 & 23.13 & Agree \\
\hline
\end{tabular}

Source: [20]

Note:

Strongly Disagree

1.00-1.80

$6.00-10.80$

Disagree

1.81-2.60

$10.81-15.60$

Quite Agree

2.61-3.40

$15.61-20.40$

Agree

3.41-4.20

$20.41-25.20$

Strongly Agree

4.21-5.00

$25.21-30.00$ 
The entrepreneurial characteristic indicator consist of 6 (six) statements, 1) Planning and anticipation related to business, 2) Management of the resources owned, 3) The desire or self-motivationn to develop business, 4) Preparation of the risks that may happen, 5) Ability to success, 6) Understanding of what is being done. The average score of 6 (six) indicators is 23.13 and can be categorized in 'Agree', so that the entrepreneurial characteristic variable helps people who have busisness to survive the pandemic.

Entrepreneurial character which is able to improve business according to Utomo, Cahyaningrum, \& Kaujan [10] is based on personal characteristic (age, education, experience, cosmopolite) and psychological characteristic (hard-working, self-confident, discipline, innovative, etc). Strong entrepreneurial characteristic are able to help business actors to survive during a pandemic in line with the concept according to Bustan [11]. Bustan explains that an entrepreneur is characterized by the characteristic of having desire to busimess and socially resposible, commitment to tasks, choose the moderate risk, keeping the ability to success, quick to see the opportunities, orientation to the future, always looking back on past achievements, thirsty attitude of 'money', skill in organization, tolerance for ambition, have the high flexibility.

The result of this study are also supported by the opinion of Purwanti in the [12] that the entrepreneurial characteristic is the need for success, each person is different in the level of need for success. People who have a low level of the need for success will satisfied with their status. Meanwhile people with high level of the need for success like to compete with the standards of exellence and choose to be personally responsible for the tasks assigned to them. The motivation to success is evident in an ambitious person who starts a new business and then want to expand the business. The characteristic of the willingness to take the risks by entrepreneurs in starting or running business are different, entrepreneurs are willing to accept the risks as they face the possibility of failure. Self-convidence characteristic on people who have confidence on themselves feel that they can answer the challenges in front of them, many successful entrepreneurs are people who have selfconfidence, admit that there is a problem but believe in their abilities to solve problems. Strong characteristic for doing business, many entrepreneurs pay attention to the level of curiousity which can be referred to a strong desire to do a business to work hard on developing their business.

\subsubsection{Business Innovation}

Business innovation is a thinking ability process, skills and resources from MSME actors to implement their thought from creative ideas so that it produces something new as products, services, proccesses, new ways, and opportunities. Innovativeness can be the starting point for entrepreneurial activities and is an essential characteristic of entrepreneurship [13]. The score that obtained from this study uses questionnaire through six indicators such as increasing quality of products, improving supply, improving the tools and production techniques, improving Standard Operating Procedures (SOP), maximizing digital marketing, and creating product innovation for new markets as measured using Likert scale.

In Table 2, it is explained that business innovation variable help MSME actors to survive the pandemic situation. Business innovation indicators consist of several statements, there are 1) Increasing quality of products, 2) Improving supply, 3) Improving the tools and production techniques, 4) Improving SOP, 5) Digital marketing (ecommerce), and 6) Creating new markets. The result of all indicators of business innovation showed by average score 4.30 that can be categorized as very high. This show that MSME actors are resistant to MSME by creating innovations. The innovations carried out are improving product quality, improving supply of raw materials and marketing system, 
improving the tools and production techniques, improving Standard Operating Procedures, online marketing (e-commerce), and creating new markets.

Table 2. Business Innovation Variable

\begin{tabular}{|c|c|c|c|c|c|c|c|c|}
\hline \multirow[t]{2}{*}{ Variable } & \multicolumn{5}{|c|}{$\begin{array}{l}\text { Distribution of Respondent's } \\
\text { Score }\end{array}$} & \multirow{2}{*}{$\begin{array}{l}\text { Score } \\
\text { Range }\end{array}$} & \multirow{2}{*}{$\begin{array}{c}\text { Score } \\
\text { Average }\end{array}$} & \multirow[t]{2}{*}{ Category } \\
\hline & 1 & 2 & 3 & 4 & 5 & & & \\
\hline \multirow{6}{*}{$\begin{array}{l}\text { Business } \\
\text { Innovation Variable }\end{array}$} & 2 & 8 & 10 & 43 & 72 & $1-5$ & 4.30 & $\begin{array}{l}\text { Very } \\
\text { High }\end{array}$ \\
\hline & 1 & 5 & 15 & 54 & 60 & $1-5$ & 4.24 & $\begin{array}{l}\text { Very } \\
\text { High }\end{array}$ \\
\hline & 1 & 9 & 24 & 45 & 56 & $1-5$ & 4.08 & High \\
\hline & 2 & 6 & 20 & 52 & 55 & $1-5$ & 4.13 & High \\
\hline & 4 & 11 & 20 & 50 & 50 & $1-5$ & 3.97 & High \\
\hline & 2 & 9 & 21 & 56 & 47 & $1-5$ & 4.01 & High \\
\hline \multicolumn{6}{|c|}{ Total } & $6-30$ & 24.73 & High \\
\hline
\end{tabular}

Source: [20]

Note:

$\begin{array}{lrr}\text { Very Low } & 1.00-1.80 & \mathbf{6 . 0 0}-\mathbf{1 0 . 8 0} \\ \text { Low } & 1.81-2.60 & \mathbf{1 0 . 8 1}-\mathbf{1 5 . 6 0} \\ \text { Moderate } & 2.61-3.40 & \mathbf{1 5 . 6 1}-\mathbf{2 0 . 4 0} \\ \text { High } & 3.41-4.20 & \mathbf{2 0 . 4 1}-\mathbf{2 5 . 2 0} \\ \text { Very High } & 4.21-5.00 & \mathbf{2 5 . 2 1}-\mathbf{3 0 . 0 0}\end{array}$

Strengthening the result of this study, Hadiyati [7] explains that innovation is an ability to apply creativity in order to solve problems and opportunities to improve and enrich life. Furthermore, the research conducted by [14] entitled "Pengaruh Inovasi dan Orientasi Kewirausahaan Terhadap Keunggulan Bersaing MSME Kuliner". The result showed that innovation varible have a significant influence on culinary competitiveness of MSME. Entrepreneurship Orientation have a significant influence on the culinary competitiveness of MSME. Little and huge business enjoy various benefits and downsides with development, however private ventures give the most helpful climate to business and advancement that are not really supported by the ability and assets normal for enormous scope creation, yet require responsibility and close participation between organization individuals [27]. Morabito, Vincenzo [28], Rahman et al. [29], and Ilić, et al. [30] revealed that there is a need for business innovation through online marketing. The research Ungarman et al. [31] has empirically confirmed that businesses con-sider the greatest impact of innovative marketing to be the increase in enterprise competitiveness, which was the highest rated impact of the research.

\subsubsection{Marketing Strategy}

Marketing strategy is an essential instrument intended to accomplish organization objectives by fostering a practical upper hands through the business sectors entered and the advertising program used to serve these market targets. Morgan, et al. [32] marketing strategy lies at the conceptual heart of the strategic marketing field. It is also central to marketing practice and the area within which many of the most pressing challenges for marketers arise. This study use a questionnaire through six indicators, namely expanding market reach, improving products, improving the packaging, observing consumer behaviour, relationship with partners, creating new markets which are measured by Likert scale. 
Table 3. Marketing Strategy Variable

\begin{tabular}{|c|c|c|c|c|c|c|c|c|}
\hline \multirow[t]{2}{*}{ Variable } & \multicolumn{5}{|c|}{$\begin{array}{l}\text { Distribution of Respondent's } \\
\text { Score }\end{array}$} & \multirow{2}{*}{$\begin{array}{l}\text { Score } \\
\text { Range }\end{array}$} & \multirow{2}{*}{$\begin{array}{l}\text { Scroe } \\
\text { Average }\end{array}$} & \multirow[t]{2}{*}{ Category } \\
\hline & 1 & 2 & 3 & 4 & 5 & & & \\
\hline \multirow{6}{*}{$\begin{array}{l}\text { Marketing } \\
\text { Strategy }\end{array}$} & 2 & 7 & 25 & 62 & 39 & $1-5$ & 3.96 & Agree \\
\hline & 1 & 7 & 41 & 61 & 25 & $1-5$ & 3.76 & Agree \\
\hline & 2 & 5 & 14 & 58 & 56 & $1-5$ & 4.19 & Agree \\
\hline & 2 & 11 & 22 & 69 & 31 & $1-5$ & 3.86 & Agree \\
\hline & 2 & 5 & 22 & 56 & 50 & $1-5$ & 4.09 & Agree \\
\hline & 2 & 5 & 25 & 64 & 39 & $1-5$ & 3.99 & Agree \\
\hline \multicolumn{6}{|c|}{ Total } & 6-30 & 23.84 & Agree \\
\hline
\end{tabular}

Source: [20]

Note:

Strongly Disagree
Disagree
Quite Agree
Agree
Strongly Agree

$1.00-1.80$

$1.81-2.60$

2.61-3.40

$3.41-4.20$

4.21-5.00

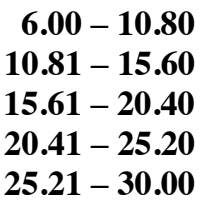

Table 3 shows that the indicator of marketing strategy help business actors survive the pandemic situation. Indicator of marketing strategy consist of several statements such as 1) Expanding market reach, 2) Product improvement to make it more quality and safe, 3) Packaging improvement, 4) Consumer behaviour to be evaluated, 5) Coorperation with external partner, 6) Creating new market. The anlysis result from indicator of marketing strategy produce an average score 23.84 and categorized as 'Agree', which means that marketing strategy are able to help MSME actors to survive during the pandemic.

Based on the research of Fauzi, Baga \& Aprilla [15] reveals that marketing strategy can be determined by making strategy mapping through SWOT analysis and making recommendation prgrams based on the results of SWOT strategy analysis. The influence of marketing strategy on the development of MSME has been investigated by Purwanti, [6]. The research uses indicators of price determination, market determination, the promotion, and products quality. The result of this study concludes that marketing strategy individually has no significant impact on the development of MSME, however, marketing strategy collectively had a significant impact. Similar studies have also been conducted by Vijaya \& Irwansyah, [6] and Faeni [17] which connected marketing strategy to business resilience and MSME development. The result of this study generally show that marketing strategy individually or collectively has a positive and significant impact on the development and resilience of MSME in business competition.

\subsection{Factors Related to resilience of MSME}

Factors related to the resilience of MSME during pandemic (new normal) comprise of the factors of pioneering trademark, business advancement, and advertising system. These elements will later influence the strength of MSME which felt by business visionaries to the strengthening program that have been executed. Coming up next is the information in regards to the degree of connection of components identified with the flexibility of MSME. 
Table 4. Correlation Factors Related to Resilence of MSME

\begin{tabular}{|l|c|c|l|}
\hline \multicolumn{1}{|c|}{ Variable } & Rs & $\boldsymbol{\alpha}$ & Description \\
\hline Entrepreneurial Characteristic & $0.498^{* *}$ & 0.000 & Significant \\
\hline Business Innovation & $0.508^{* *}$ & 0.000 & Significant \\
\hline Marketing Strategy & $0.975^{* *}$ & 0.000 & Significant \\
\hline
\end{tabular}

Source : [20]

Note:** Correlation level at 0.01 or confidence level on $99 \%$

Based on the calculation data of the correlation of factors related to resilience of MSME above, it can be seen that:

\subsubsection{The Resilience of MSME With The Entrepreneurial Characteristic}

The result of the table 4 shows that the correlation coefficient between the resilience of MSME and entrepreneurial characteristic is 0.498 so that it has a significant correlation level and has a value $\alpha 0.000<0.05$ or 0.01 or at $99 \%$ of confidence level. It means that H0 is accepted and $\mathrm{Ha}$ is rejected, so it concludes that there is an influence between the resilience of MSME and the entrepreneurial characteristic with the positive correlation value, which means that the correlation between these variables are unidirectional, so that the greater entrepreneurial characteristic, the higher resilience of MSME.

This is in line with the research of [6] which expalins that there is a positive and significant impact of entrepreneurial characteristic factors on the resilience of MSME. This can be explained that in order to achive business resilience as expected, an entrepreneurs must have the ability to create innovation on looking for new things so there is not to be left behind with the development of products on the market and always have the desire to be able to compete with the opportunity, have a courage to be responsible for the quality of products produced, and have a courage to accept suggestion and challenges for the products produced. Satyarini [18] mentioned that entrepreneurial characteristic that has a strong influence on business future orientation is leadership spirit. Rimiyati \& Munawaroh [19] also mentioned that having leadership spirit including the ability to delegate or entrust work to the workers and manage them so that they will have loyal workers and have a high productivity.

\subsubsection{The Resilience of MSME with The Business Innovation}

The result of the table above shows that the correlation coefficient between the resilience of MSME and business innovation is 0.509 so that it has a significant correlation level and has a value $\alpha 0.000<0.05$ or 0.01 or at $99 \%$ of confidence level. It means that H0 is accepted and $\mathrm{Ha}$ is rejected, so it concludes that there is an influence between the resilience of MSME and the business innovation with the positive correlation value, which means that the correlation between these variables are unidirectional, so that the more business innovation, the higher resilience of MSME.

This is in line with the research of [14] which says that business innovation have a significant impact on business exellence and resilience to compete. This can be explained that a businesses that are able to introduce the innovation can lead and minimize the possibility of the competitor to innovate early so that the business can survive and have competitiveness with other competitor. 


\subsubsection{The Resilience of MSME with The Marketing Strategy}

The result of the table above shows that the correlation coefficient between the resilience of MSME and marketing strategy is 0.975 so that it has an extremely strong correlation level and has a value $\alpha 0.000<0.05$ or 0.01 or at $99 \%$ of confidence level. It means that H0 is accepted and $\mathrm{Ha}$ is rejected, so it concludes that there is an influence between the resilience of MSME and the marketing strategy with the positive correlation value, which means that the correlation between these variables are unidirectional, so that the wider marketing strategy, the stronger resilience of MSME.

This is in line with the research of [16] which says that marketing strategy have a significant impact on business development and resilience. This can be clarified that in confronting an undeniably open and serious market component, market control is an essential for expanding the intensity of MSME. To overwhelm the market, MSME need to get the data effectively and rapidly, both data about creation market and the market for creation factors. The data about prodcution market is extremely important to grow the promoting organization of items by MSME. Complete and precise market data can be utilized by MSME to make legitimate business arranging. Along these lines, the job of goverment is extremely vital in empowering the achievement of MSME in accessing extend showcasing network.

\section{Conclusion}

The perception of the resilience of MSME with the variables of entrepreneurial characteristic, business innovation, and marketing strategy includes in 'Agree' category, which concluded that these 3 (three) variables help MSME actors to survive during pandemic. The indicators that have important role in each variables are (1) Having high productivity; (2) Having a courage for being responsible; (3) Product creativity development; (4) Market control. Factors related to the resilience of MSME are entrepreneurial characteristic, business innovation, and marketing strategy, each have positivite value and significant, which means that there is influence on resilience of MSME during the pandemic in new normal.

\section{References}

1. S. Sudjinan, \& J. Juwari. JAMIE. Pemberdayaan Potensi Masyarakat Melalui Pendampingan MSME Dan Koperasi Di Kelurahan Telaga Sari Kota Balikpapan. 1.01. $40-49 .(2018)$

2. M. M. Manahera, S. Moniharapon, \& H. N. Tawas. J. EMBA. Analisis Pengaruh Orientasi Pasar, Orientasi Kewirausahaan Terhadap Inovasi Produk Dan Kinerja Pemasaran (Studi Kasus MSME Nasi Kuning di Manado). 6.4. (2018)

3. R. Sudaryanto, \& R. R. Wijayanti. Pusat Kebijakan Ekonomi Makro, Badan Kebijakan Fiskal, Kementerian Keuangan, Jakarta. Strategi pemberdayaan MSME menghadapi pasar bebas Asean. (2013)

4. A. Amri. BRAND J. Dampak Covid-19 Terhadap MSME di Indonesia. 2.1. 123 - 131 (2020)

5. K. Sedyastuti. INOBIS J. Analisis Pemberdayaan MSME Dan Peningkatan Daya Saing Dalam Kancah Pasar Global. 2(1), 117-127. (2018). 
6. E. Purwanti. Among Makarti. Pengaruh Karakteristik Wirausaha, Modal Usaha, Strategi Pemasaran Terhadap Perkembangan MSME Di Desa Dayaan Dan Kalilondo Salatiga.5.1. (2013).

7. E. Hadiyati. A.J.Inn.Entr. Kreativitas Dan Inovasi Pengaruhnya Terhadap Pemasaran Kewirausahaan Pada Usaha Kecil. 1(3). 135 - 151. (2012).

8. M. Nazir. Jakarta: Ghalia Indonesia. Metode Penelitian. (2013).

9. Slamento dan Handayani. Jakarta: Rineka Cipta.. Belajar dan Faktor-Faktor Mempengaruhi. (2013)

10. M. N. Utomo, W. Cahyaningrum, K. Kaujan. J. Man. Bis. The Role Of Entrepreneur Characteristic And Financial Literacy In Developing Business Success. 11.1. 26 - 42 (2020).

11. J. Bustan. J. Man. Bis. S. Pengaruh Karakteristik Wirausaha, Orientasi Pembelajaran Dan Orientasi Kewirausahaan Terhadap Keberhasilan Usaha. 14.1. 29 - 42. (2016).

12. Justin et al. South-Western College Publishing. Kewirausahaan. (2000).

13. C. Chairy. J. Man. Bis. Pengaruh Karakteristik Entrepreneurial, Jenis Etnis, Jenis Kelamin dan Profesi Orang Tua Terhadap Intensi Berwirausaha Mahasiswa. 1(2). 245 259. (2011).

14. I. Lestari, M. Astuti, H. Ridwan. JRMB Fakultas Ekonomi UNIAT. Pengaruh Inovasi Dan Orientasi Kewirausahaan Terhadap Keunggulan Bersaing MSME Kuliner. 4(1), 111-118. (2019).

15. D. Fauzi, L. M. Baga, N. Tinaprilla. AGRARIS. Strategi Pengembangan Agribisnis Kentang Merah di Kabupaten Solok. 2(1). 87 - 96. (2016)

16. D. P. Vijaya, M. R. Irwansyah. Ekuitas. Pengaruh Modal Psikologis, Karakteristik Wirausaha, Modal Usaha Dan Startegi Pemasaran Terhadap Perkembangan Usaha MSME Di Kecamatan Buleleng Tahun 2017. 5(1). (2018).

17. D. Faeni. J. Eko. Man. Karakteristik Manajer, Pembaruan SDM, Strategi Pemasaran, Motivasi Bermitra, Orientasi Kerja, Standarisasi Kerja, Terhadap Ketahanan Bisnis UKM Dalam Persaingan Usaha: Study UKM di Jakarta Indonesia. 4(1). (2015).

18. T. B. Satyarini. AGRARIS. Karakter Wirausaha pada Industri Mikro Pangan Olahan di DIY dan Faktor-Faktor yang Mempengaruhi. 2(1). 28 - 35. (2016)

19. H. Rimiyati, M. Munawaroh. J. Man. Bis. Pengaruh Penerapan Nilai-Nilai Kewirausahaan Islami Terhadap Keberhasilan Usaha (Studi Pada Pengusaha UMKM Muslim Di Kota Yogyakarta). 7(2). 130 - 157. (2016)

20. Kementerian Koperasi dan Usaha Kecil Menengah. "Perkembangan Data Usaha Mikro, Kecil, Menengah (MSME) dan Usaha Besar (UB) Tahun 2017-2018.” Diakses 20 September 2020.

21. Mulyadi H, Hendrayati H. SMEs Resilience During the Covid-19 Pandemic: A Case Study in Indonesia. In5th Global Conference on Business, Management and Entrepreneurship (2021).

22. Osano, H.M. Global expansion of SMEs: role of global market strategy for Kenyan SMEs. J Innov Entrep 8, 13 (2019).

23. Badoc-Gonzales, Blesilda P., Ma Belinda S. Mandigma, and Jackson J. Tan. Resilience and sustainability interventions in selected Post-Haiyan Philippines: MSMEs perspective. International Journal of Disaster Risk Reduction 57 (2021). 
24. Rochman, Gina Puspitasari, Imam Indratno, and Ina Helena Agustina. Rural Agri-Food Industry Resilience in Indonesia. IOP Conference Series: Earth and Environmental Science. Vol. 830. No. 1. IOP Publishing, (2021).

25. Hanggraeni, Dewi, Beata Ślusarczyk, Liyu Adhi Kasari Sulung, and Athor Subroto. The impact of internal, external and enterprise risk management on the performance of micro, small and medium enterprises. Sustainability 11(7). (2019).

26. Franco, Mário, Heiko Haase, and Dalne António. Influence of failure factors on entrepreneurial resilience in Angolan micro, small and medium-sized enterprises. International Journal of Organizational Analysis (2020).

27. Sahut, Jean-Michel, and Marta Peris-Ortiz. Small business, innovation, and entrepreneurship. Small Business Economics 42(4). (2014).

28. Morabito, Vincenzo. Business innovation through blockchain. Cham: Springer International Publishing (2017).

29. Rahman, Nurulhasanah Abdul, Zulnaidi Yaacob, and Rafisah Mat Radzi. An overview of technological innovation on SME survival: a conceptual paper." Procedia-Social and Behavioral Sciences 224. (2016).

30. Ilić, Dejan, Slavica Ostojić, and Nemanja Damnjanović. The importance of marketing innovation in new economy. The European Journal of Applied Economics 11(1). (2014).

31. Ungerman, Otakar, Jaroslava Dedkova, and Katerina Gurinova. The impact of marketing innovation on the competitiveness of enterprises in the context of industry 4.0. Journal of Competitiveness 10(2). (2018).

32. Morgan, Neil A., Kimberly A. Whitler, Hui Feng, and Simos Chari. Research in marketing strategy. Journal of the Academy of Marketing Science 47(1). (2019). 